\title{
Immunosurveillance of Cancer and Viral Infections with Regard to Alterations of Human NK Cells Originating from Lifestyle and Aging
}

\author{
Xuewen Deng ${ }^{1, *}$, Hiroshi Terunuma ${ }^{1,2}$ and Mie Nieda ${ }^{1}$ \\ 1 Biotherapy Institute of Japan, Inc., 2-4-8 Edagawa, Koto-ku, Tokyo 135-0051, Japan; \\ terunuma@bij-net.com (H.T.); nieda.bij@gmail.com (M.N.) \\ 2 N2 Clinic Yotsuya, 5F 2-6 Samon-cho, Shinjuku-ku, Tokyo 160-0017, Japan \\ * Correspondence: tohxuewen@bij-net.com; Tel.: +81-3-5632-6080; Fax: +81-3-5632-6083
}

check for updates

Citation: Deng, X.; Terunuma, H.; Nieda, M. Immunosurveillance of Cancer and Viral Infections with Regard to Alterations of Human NK Cells Originating from Lifestyle and Aging. Biomedicines 2021, 9, 557. https://doi.org/10.3390/ biomedicines 9050557

Academic Editors: Veronique Baud and Amedeo Amedei

Received: 22 March 2021

Accepted: 14 May 2021

Published: 17 May 2021

Publisher's Note: MDPI stays neutral with regard to jurisdictional claims in published maps and institutional affiliations.

Copyright: (c) 2021 by the authors. Licensee MDPI, Basel, Switzerland. This article is an open access article distributed under the terms and conditions of the Creative Commons Attribution (CC BY) license (https:// creativecommons.org/licenses/by/ $4.0 /)$.

\begin{abstract}
Natural killer (NK) cells are cytotoxic immune cells with an innate capacity for eliminating cancer cells and virus- infected cells. NK cells are critical effector cells in the immunosurveillance of cancer and viral infections. Patients with low NK cell activity or NK cell deficiencies are predisposed to increased risks of cancer and severe viral infections. However, functional alterations of human NK cells are associated with lifestyles and aging. Personal lifestyles, such as cigarette smoking, alcohol consumption, stress, obesity, and aging are correlated with NK cell dysfunction, whereas adequate sleep, moderate exercise, forest bathing, and listening to music are associated with functional healthy NK cells. Therefore, adherence to a healthy lifestyle is essential and will be favorable for immunosurveillance of cancer and viral infections with healthy NK cells.
\end{abstract}

Keywords: NK cell; immunosurveillance; lifestyle; aging; cancer; viral infection

\section{Introduction}

The average global life expectancy has increased substantially over the past few decades [1]. The aging of the population has led to a high prevalence of chronic diseases such as cancer [2]. People with cancer have 5.8-11.2 years shorter life expectancy than their peers without cancer [3]. Lifestyles affect the incidence of chronic diseases including cancer and life expectancy [4]. Lifestyle factors including cigarette smoking, alcohol consumption, physical exercise, stress, obesity, sleep, forest bathing, and listening to music. Healthy lifestyles are related to a long life expectancy free from major diseases such as cancer [5] and higher resistance to viral infections. Conversely, unhealthy lifestyles contribute to the progression of severe diseases of such as COVID-19 [6] and increased risk of cancer progression [7]. Therefore, the promotion of a healthy lifestyle is critical to the defense against cancer and viral infections, and in improving life expectancy free of cancer and other associated chronic diseases [5]. In this paper, we review the immunosurveillance of cancer and viral infections with regard to alterations of natural killer (NK) cells originating from lifestyles and aging.

\section{NK Cells}

NK cells were first identified in 1975 from the observation of their natural capacity to kill tumor cells without prior in vivo sensitization [8,9]. NK cells originate from the bone marrow, and human NK cells comprise 5-20\% of all lymphocytes and are defined phenotypically by their expression of CD56 and lack of CD3 expression. Two distinct populations of human NK cells could be identified, based upon their cell-surface density of CD56. The majority of human NK cells have low-density expression of CD56 (CD56 ${ }^{\mathrm{dim}}$ ) and expression high levels of CD16, which comprise about $90 \%$ of peripheral blood NK cells, whereas $10 \%$ of NK cells are CD56 $6^{\text {bright }} C D 16^{\text {dim }}$ or $C D 56^{\text {bright }} C D 16^{\text {negative }}$. The CD56 ${ }^{\text {dim }}$ subset is more 
naturally cytotoxic, whereas the CD56 $6^{\text {bright }}$ subset, which is localized in lymphoid tissue has the capacity to produce abundant cytokines [10-12]. However, CD56 ${ }^{\text {bright }}$ NK cells can also become cytotoxic upon appropriate activation and play roles in different disease states, such as cancer and infections [13]. NK cell functions are tightly regulated by a balance of activating and inhibitory germline-encoded receptors [14-16]. Healthy cells express major histocompatibility complex class I (MHC-I) molecules, which mark these cells as "self". MHC-I molecules act as ligands for inhibitory receptors on NK cells and contribute to "self-tolerance", by preventing the-killing of these healthy cells by NK cells $[15,17]$. The MHC-I-specific inhibitory receptors include killer cell immunoglobulin-like receptors (KIRs) and lectin-like CD94-NKG2A heterodimers [15,16].

\section{NK Cell Immunosurveillance of Cancer and Viral Infections}

Cancer cells and virus-infected cells, down regulate MHC-I expression, which impairs the engagement with inhibitory receptors on NK cells, and lowers the inhibitory signaling threshold [15,17-19]. In addition, cancer cells and virus- infected cells upregulate NK cell activity ligands, which in response to NK-cell -activating receptors, such as NKG2D, CD244, NKp30, and NKp46, induce signaling pathways that trigger NK cell responses $[15,16]$. The coactivation of these receptors overcomes the NK regulatory balance to mount an effective response against cancer cells and virus- infected cells [15]. NK cell activation can result in direct lysis of target cells, through cytotoxic degranulation by perforin and granzyme B [15], and the simultaneous production of inflammatory cytokines, such as interferon- $\gamma$ and tumor necrosis factor- $\alpha$, which activate other immune components including adaptive response components $[17,20]$.

NK cells play key roles in host defense against viral infections [21,22]. In humans, NK cells are important to the innate immune response against members of the herpesvirus, poxvirus, and papillomavirus families $[23,24]$. Patients with identified NK cell deficiencies are predisposed to particularly severe, recurrent viral infection [24,25]. Mouse models provide additional evidence that NK cells critically help in the control of several viral infections, most notably murine cytomegalovirus, poxviruses, and influenza viruses [26,27].

Since their discovery, a numerous studies have demonstrated the NK-cell-mediated killing of many types of tumor cell line in vitro in experimental animal models [28-33]. NK cells contribute to the immunosurveillance of human cancer [34]. A prospective cohort study of 3625 people from the general population with 11-year follow up for cancer incidence and death indicated that people with medium or high NK cell activity had a reduced risk of cancer, whereas those with low NK cell activity manifested an increased cancer risk [35]. Additionally, patients with cancer, such as colorectal cancer [36], prostate cancer [37], and breast cancer [38] had decreased NK cell activity. Patients with metastatic cancer had furthermore decreased NK cell activity [38]. Several studies have demonstrated that a high degree of intratumoral infiltration of NK cells is associated with a favorable outcome [39-41]. Moreover, NK cell activity predicted the response to chemotherapy and immunotherapy for patients with cancer [42-44]. Therefore, functional healthy NK cells are critical for anti-tumor and anti-virus immunities, whereas NK cell dysfunction increases the vulnerability to viral infections and cancer (Figure 1). 


\section{A Healthy NK cell}

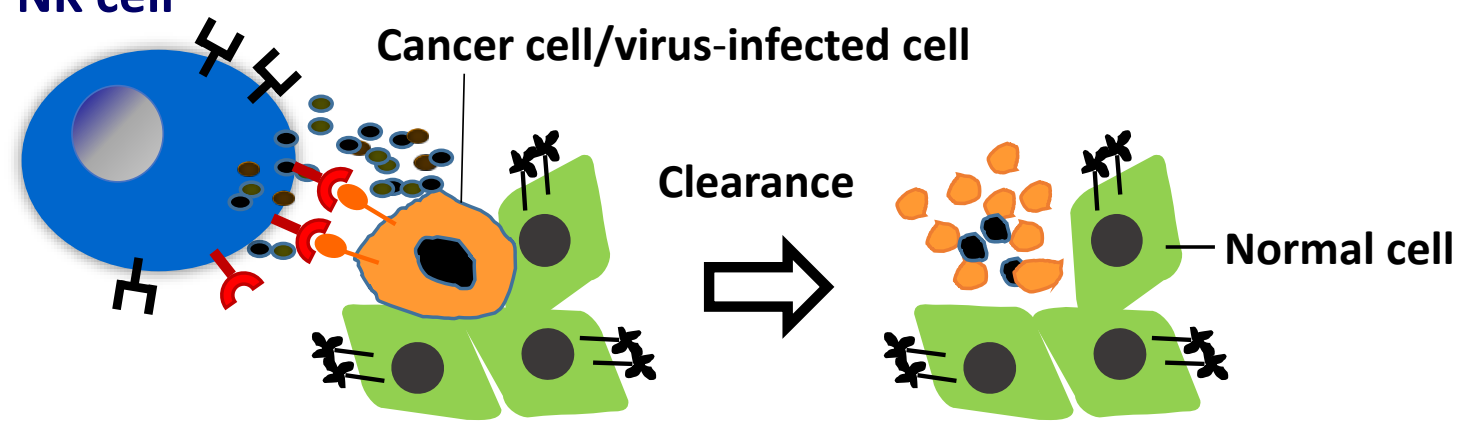

\section{B Dysfunctional NK cell}
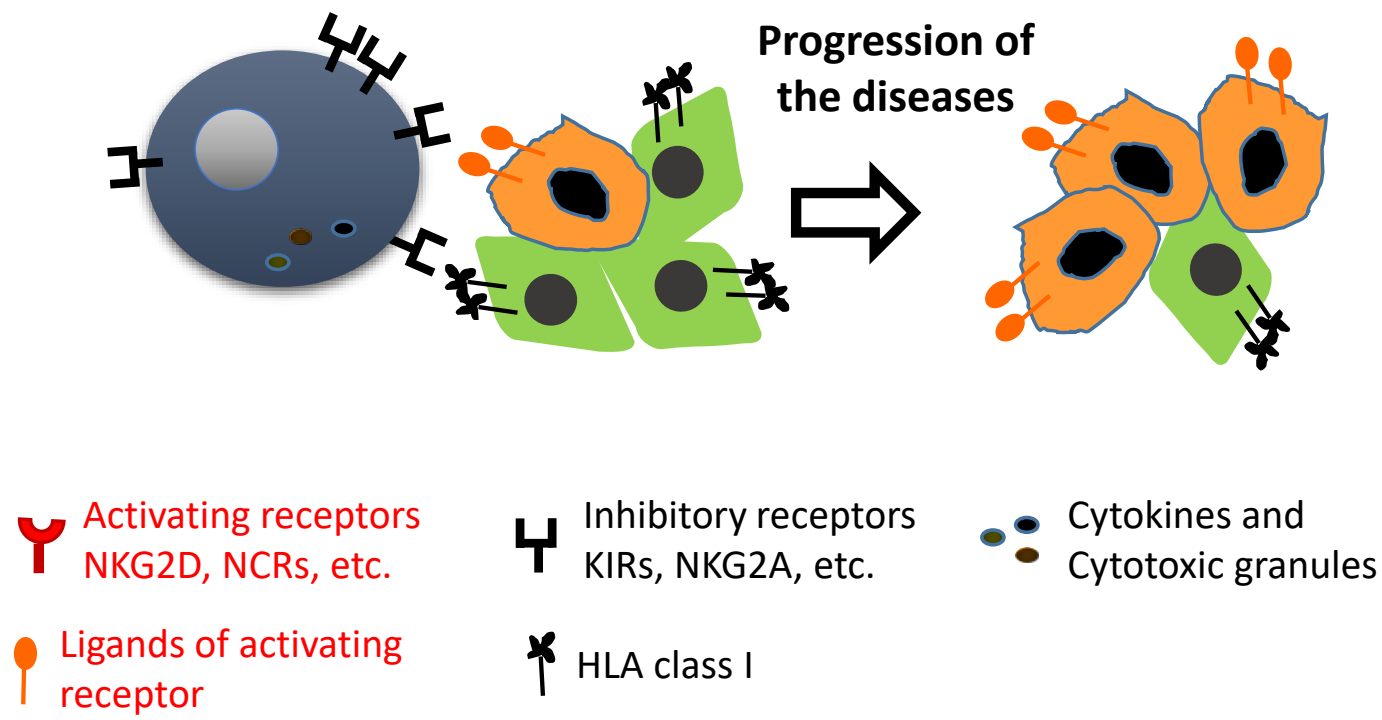

Figure 1. Schematic depiction of NK cell immunosurveillance of cancer and viral infections. (A): Healthy NK cells expressing activating receptors can recognize virus- infected cells and cancer cells, and release sufficient amount of cytotoxic granules and cytokines to kill and clear virus-infected cells and cancer cells. (B): Dysfunctional NK cells expressing an imbalance of activating and inhibitory receptors with high expression of inhibitory receptors, malfunctions in the recognition of cancer and virus-infected cells and the release of cytotoxic granules and cytokines to kill them, evasion of immunosurveillance of viral infections and cancer, and the spread of viral infections and progression of cancer.

\section{Lifestyles and NK Cells}

Owing to the unique capacities of NK cells in host immunoprotection, especially anti-tumor and anti-viral immunities, research data on NK cells in relation to lifestyles have accumulated over the past decades since the 1980s (Table 1). In this paper we provide an updated overview of the association of human NK cells with personal lifestyles, such as cigarette smoking, alcohol consumption, stress, obesity, sleep, exercise, forest bathing and listening to music. In particular, we examine findings of human studies on the alterations of NK cell count, percentage, subsets, phenotype, activity, cytokine secretion, and functional granule components in association with lifestyles. 
Table 1. Overview of Lifestyles Associated Alterations of Human NK Cells.

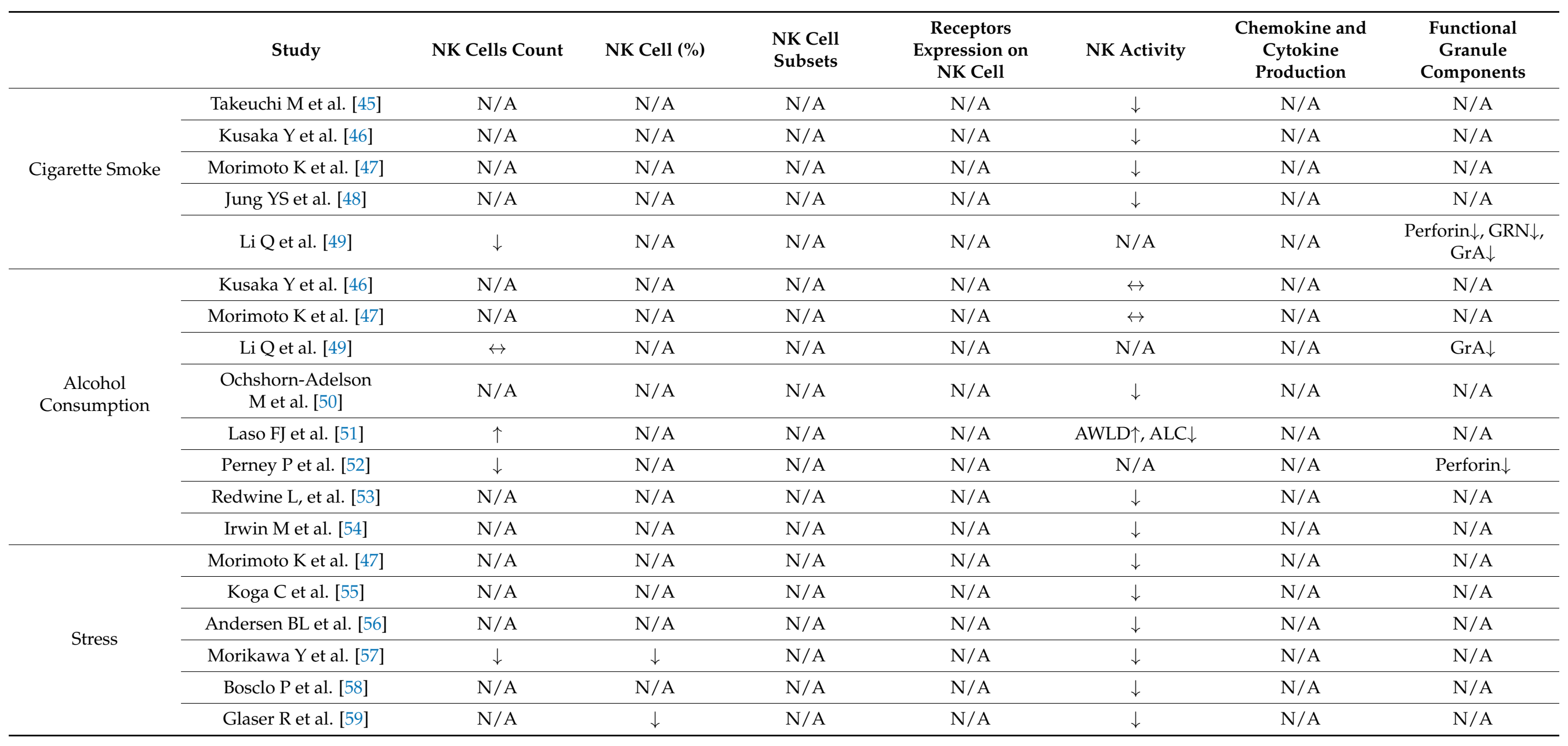


Table 1. Cont.

\begin{tabular}{|c|c|c|c|c|c|c|c|c|}
\hline & Study & NK Cells Count & NK Cell (\%) & $\begin{array}{l}\text { NK Cell } \\
\text { Subsets }\end{array}$ & $\begin{array}{l}\text { Receptors } \\
\text { Expression on } \\
\text { NK Cell }\end{array}$ & NK Activity & $\begin{array}{c}\text { Chemokine and } \\
\text { Cytokine } \\
\text { Production }\end{array}$ & $\begin{array}{l}\text { Functional } \\
\text { Granule } \\
\text { Components }\end{array}$ \\
\hline \multirow{6}{*}{ Obesity } & Lynch LA et al. [60] & $\mathrm{N} / \mathrm{A}$ & $\downarrow$ & $\mathrm{N} / \mathrm{A}$ & $\begin{array}{c}\mathrm{NKB1} \uparrow, \mathrm{CD} 158 \mathrm{~b} \uparrow, \\
\mathrm{CD} 69 \uparrow\end{array}$ & $\mathrm{N} / \mathrm{A}$ & $\mathrm{N} / \mathrm{A}$ & $\mathrm{N} / \mathrm{A}$ \\
\hline & Tobin LM et al. [61] & $\downarrow$ & $\downarrow$ & $\mathrm{N} / \mathrm{A}$ & 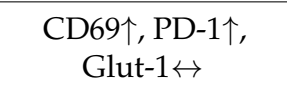 & $\downarrow$ & IFN- $\gamma \leftrightarrow$ & GrB $\downarrow$, Perforin $\downarrow$ \\
\hline & Bahr I et al. [62] & $\mathrm{N} / \mathrm{A}$ & $\leftrightarrow$ & $\begin{array}{c}\text { CD56 } 6^{\text {bright }} \uparrow, \\
\text { CD56 } 6^{\text {dim }} \downarrow\end{array}$ & $\begin{array}{c}\text { CD56 bright: } \\
\text { NKG2D } \uparrow, \\
\text { CD56 } \\
\text { NKG2D: } \\
\text { NK, CD69 } \downarrow\end{array}$ & $\mathrm{N} / \mathrm{A}$ & $\begin{array}{c}\text { CD56 } 6^{\text {bright: }} \\
\text { IFN- } \gamma \uparrow, \\
\text { CD56 }{ }^{\text {dim }}: \text { IFN- } \gamma \downarrow\end{array}$ & $\mathrm{N} / \mathrm{A}$ \\
\hline & Naujoks W et al. [63] & $\mathrm{N} / \mathrm{A}$ & $\leftrightarrow$ & $\leftrightarrow$ & 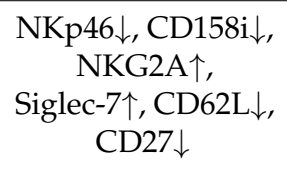 & $\downarrow$ & $\mathrm{N} / \mathrm{A}$ & TRAIL $\downarrow$ \\
\hline & Laue T et al. [64] & $\mathrm{N} / \mathrm{A}$ & $\leftrightarrow$ & $\leftrightarrow$ & TRAIL $\downarrow$, CD107a $\downarrow$ & $\mathrm{N} / \mathrm{A}$ & $\mathrm{N} / \mathrm{A}$ & $\mathrm{N} / \mathrm{A}$ \\
\hline & Viel S et al. [65] & $\leftrightarrow$ & $\leftrightarrow$ & $\mathrm{N} / \mathrm{A}$ & $\begin{array}{c}\mathrm{NKp} 46 \downarrow, \mathrm{CD} 94 \downarrow, \\
\mathrm{CD} 69 \uparrow, \\
\mathrm{CD} 16 \downarrow, \mathrm{CD} 107 \mathrm{a} \downarrow\end{array}$ & $\mathrm{N} / \mathrm{A}$ & IFN- $\gamma \leftrightarrow$, MIP1- $\beta \downarrow$ & $\mathrm{GrB} \uparrow$ \\
\hline \multirow{4}{*}{ Sleep deprivation } & Irwin $\mathrm{M}$ et al. [66] & $\mathrm{N} / \mathrm{A}$ & $\mathrm{N} / \mathrm{A}$ & $\mathrm{N} / \mathrm{A}$ & $\mathrm{N} / \mathrm{A}$ & $\downarrow$ & $\mathrm{N} / \mathrm{A}$ & $\mathrm{N} / \mathrm{A}$ \\
\hline & Irwin $\mathrm{M}$ et al. [67] & $\downarrow$ & $\downarrow$ & $\mathrm{N} / \mathrm{A}$ & $\mathrm{N} / \mathrm{A}$ & $\downarrow$ & $\mathrm{N} / \mathrm{A}$ & $\mathrm{N} / \mathrm{A}$ \\
\hline & Moldofsky H et al. [68] & $\mathrm{N} / \mathrm{A}$ & $\mathrm{N} / \mathrm{A}$ & $\mathrm{N} / \mathrm{A}$ & $\mathrm{N} / \mathrm{A}$ & $\downarrow$ & $\mathrm{N} / \mathrm{A}$ & $\mathrm{N} / \mathrm{A}$ \\
\hline & Dinges DF et al. [69] & $\uparrow$ & $\mathrm{N} / \mathrm{A}$ & $\mathrm{N} / \mathrm{A}$ & $\mathrm{N} / \mathrm{A}$ & $\uparrow$ & $\mathrm{N} / \mathrm{A}$ & $\mathrm{N} / \mathrm{A}$ \\
\hline
\end{tabular}


Table 1. Cont.

\begin{tabular}{|c|c|c|c|c|c|c|c|c|}
\hline & Study & NK Cells Count & NK Cell (\%) & $\begin{array}{l}\text { NK Cell } \\
\text { Subsets }\end{array}$ & $\begin{array}{c}\text { Receptors } \\
\text { Expression on } \\
\text { NK Cell }\end{array}$ & NK Activity & $\begin{array}{c}\text { Chemokine and } \\
\text { Cytokine } \\
\text { Production }\end{array}$ & $\begin{array}{c}\text { Functional } \\
\text { Granule } \\
\text { Components }\end{array}$ \\
\hline \multirow{6}{*}{ Exercise } & Li Q et al. [49] & $\uparrow$ & $\mathrm{N} / \mathrm{A}$ & $\mathrm{N} / \mathrm{A}$ & $\mathrm{N} / \mathrm{A}$ & $\mathrm{N} / \mathrm{A}$ & $\mathrm{N} / \mathrm{A}$ & $\begin{array}{c}\text { Perforin } \uparrow, \mathrm{GRN} \uparrow, \\
\mathrm{GrA} \uparrow, \mathrm{GrB} \uparrow\end{array}$ \\
\hline & Nieman DC et al. [70] & $\leftrightarrow$ & $\uparrow$ & $\mathrm{N} / \mathrm{A}$ & $\mathrm{N} / \mathrm{A}$ & $\uparrow$ & $\mathrm{N} / \mathrm{A}$ & $\mathrm{N} / \mathrm{A}$ \\
\hline & Pedersen BK et al. [71] & $\mathrm{N} / \mathrm{A}$ & $\uparrow$ & $\mathrm{N} / \mathrm{A}$ & $\mathrm{N} / \mathrm{A}$ & $\uparrow$ & $\mathrm{N} / \mathrm{A}$ & $\mathrm{N} / \mathrm{A}$ \\
\hline & $\begin{array}{l}\text { Moro-Garcia } \\
\text { MA et al. [72] }\end{array}$ & $\mathrm{N} / \mathrm{A}$ & $\uparrow$ & $\mathrm{N} / \mathrm{A}$ & $\mathrm{N} / \mathrm{A}$ & $\uparrow$ & $\mathrm{N} / \mathrm{A}$ & $\mathrm{N} / \mathrm{A}$ \\
\hline & Jung YS et al. [73] & $\mathrm{N} / \mathrm{A}$ & $\mathrm{N} / \mathrm{A}$ & $\mathrm{N} / \mathrm{A}$ & $\mathrm{N} / \mathrm{A}$ & $\uparrow$ & $\mathrm{N} / \mathrm{A}$ & $\mathrm{N} / \mathrm{A}$ \\
\hline & Nieman DC et al. [74] & $\leftrightarrow$ & $\mathrm{N} / \mathrm{A}$ & $\mathrm{N} / \mathrm{A}$ & $\mathrm{N} / \mathrm{A}$ & $\uparrow$ & $\mathrm{N} / \mathrm{A}$ & $\mathrm{N} / \mathrm{A}$ \\
\hline \multirow{4}{*}{ Forest bathing } & Li Q et al. [75] & $\mathrm{N} / \mathrm{A}$ & $\uparrow$ & $\mathrm{N} / \mathrm{A}$ & $\mathrm{N} / \mathrm{A}$ & $\uparrow$ & $\mathrm{N} / \mathrm{A}$ & $\begin{array}{c}\text { Perforin } \uparrow, \mathrm{GRN} \uparrow, \\
\mathrm{GrA} \uparrow, \mathrm{GrB} \uparrow\end{array}$ \\
\hline & Li Q et al. [76] & $\uparrow$ & $\uparrow$ & $\mathrm{N} / \mathrm{A}$ & $\mathrm{N} / \mathrm{A}$ & $\uparrow$ & $\mathrm{N} / \mathrm{A}$ & $\begin{array}{c}\text { Perforin } \uparrow, \mathrm{GRN} \uparrow, \\
\mathrm{GrA} \uparrow, \mathrm{GrB} \uparrow\end{array}$ \\
\hline & Li Q et al. [78] & $\uparrow$ & $\uparrow$ & $\mathrm{N} / \mathrm{A}$ & $\mathrm{N} / \mathrm{A}$ & $\uparrow$ & $\mathrm{N} / \mathrm{A}$ & $\begin{array}{c}\text { Perforin } \uparrow, \mathrm{GRN} \uparrow, \\
\mathrm{GrA} \uparrow, \mathrm{GrB} \uparrow\end{array}$ \\
\hline & Li Q [79] & $\uparrow$ & $\mathrm{N} / \mathrm{A}$ & $\mathrm{N} / \mathrm{A}$ & $\mathrm{N} / \mathrm{A}$ & $\uparrow$ & $\mathrm{N} / \mathrm{A}$ & $\begin{array}{c}\text { Perforin } \uparrow, \mathrm{GrA} \uparrow, \\
\mathrm{GrB} \uparrow\end{array}$ \\
\hline \multirow{3}{*}{ Music } & Wachi M et al. [80] & $\mathrm{N} / \mathrm{A}$ & $\uparrow$ & $\mathrm{N} / \mathrm{A}$ & $\mathrm{N} / \mathrm{A}$ & $\uparrow$ & 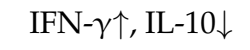 & $\mathrm{N} / \mathrm{A}$ \\
\hline & Koyama M et al. [81] & $\leftrightarrow$ & $\mathrm{N} / \mathrm{A}$ & $\mathrm{N} / \mathrm{A}$ & $\mathrm{N} / \mathrm{A}$ & $\leftrightarrow$ & $\mathrm{N} / \mathrm{A}$ & $\mathrm{N} / \mathrm{A}$ \\
\hline & Hasegawa Y et al. [82] & $\mathrm{N} / \mathrm{A}$ & $\uparrow$ & $\mathrm{N} / \mathrm{A}$ & $\mathrm{N} / \mathrm{A}$ & $\uparrow$ & $\mathrm{N} / \mathrm{A}$ & $\mathrm{N} / \mathrm{A}$ \\
\hline
\end{tabular}

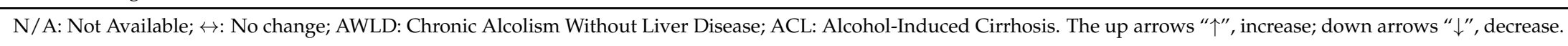




\subsection{Cigarette Smoking}

Cigarette smoke is a major health risk factor that increases the risk of developing many types of cancer [83]. In a murine lung metastasis model, cigarette smoking impaired NK-cell-dependent tumor immunosurveillance, and the resulting altered immunity was associated with an increased tumor burden [84]. Studies in humans have shown that NK cell activity is reduced in smokers [45-48]. Recently, a large cross-sectional study has shown an inverse correlation between NK cell activity and the number cigarettes smoked daily, and the total number of cigarettes smoked [48]. Cigarette smoke reduces the cytolytic granules of perforin, granzymes, and granulysin on NK cells [49].

These finding suggest that cigarette smoking compromises NK cell function, enabling cancer cells to evade immunosurveillance.

\subsection{Alcohol Consumption}

Chronic heavy consumption of alcohol by humans has been implicated as an etiological factor or cofactor in various types of cancer [85]. Alcohol is known to have a generally suppressive effect on the immune system in humans $[86,87]$. However, research data about the effects of alcohol on NK cell activity are conflicting [50]. There are results indicating the NK cell count in the peripheral blood is increased [51] or decreased [52] by alcohol. Some results have shown an alcohol-related decrease in NK cell activity [53,54], while other studies did not find any significant effect of alcohol on NK cell activity [46-48]. A study of nonalcoholic male volunteers administered alcohol either intravenously or orally to has showed that a single dose did not alter NK cell activity even when the blood alcohol concentrations reached $89 \mathrm{mg} / \mathrm{dl}$. However, when NK cells are exposed to alcohol in vitro for $4 \mathrm{~h}$ at concentrations of $80 \mathrm{mg} / \mathrm{dl}$ and above, a significant concentration-dependent decrease in NK cell activity was observed [50]. Another study comparing the effects of alcohol on NK cells between patients with chronic alcoholism without liver disease (AWLD) and those with alcohol-induced cirrhosis (ALC) has shown that alcohol by itself induces an increase in the number and activity of NK cells in peripheral blood. In contrast, the NK cell activity is constantly depressed in the stage of alcoholic cirrhosis, suggesting that the behavior of NK cells in peripheral blood in chronic alcoholism differs depending on the presence or absence of ALC [51]. In addition, the level of perforin expression by NK cells is decreased in patients with chronic alcoholism [52]. The alterations of NK cells induced by chronic alcohol consumption, particularly in the stage of alcoholic cirrhosis, causes decreased immunosurveillance, which may contribute to the higher incidence of cancer.

\subsection{Stress}

Psychological stress affects various immune functions [88]. The hypothalamic-pituitaryadrenal (HPA) axis has been considered as a pathway along which psychological stress- is transposed into an impaired immune function [89]. NK cells express adrenergic receptors, which respond to catecholamines triggered by a stress response [90]. Subjects who complained of an unstable mental state have lower NK cell activity than those who reported a stable mental state [47]. Anxiety about cancer suppresses NK cell activity [55]. Stress levels in patients with breast cancer negatively correlated with NK cell activity [56]. Chronic job stress is associated with decreased NK cell count, proportion, and activity in peripheral blood [57]. People with job insecurity have decreased NK cell activity [58]. Stress depresses interferon (IFN) production by leukocytes concomitant with decreased NK cell activity [59]. Therefore, stress increases vulnerability to cancer and viral infections.

\subsection{Obesity}

Obesity increases the risk of many cancers and severe COVID-19 infection [91,92], and is responsible for up to $40 \%$ of cases of cancer [93]. Obesity drives chronic inflammation, which precedes the development of comorbid diseases including cancer [94]. NK cell anti-tumor responses are negatively regulated in obesity [95]. The number of NK cells is decreased in obese people $[60,61]$, and is further decreased in obese people with unhealthy 
metabolic profiles [60]. There are increased CD56 $6^{\text {bright }} \mathrm{NK}$ subset and decreased CD56 ${ }^{\text {dim }}$ subset in obese people, and correlates with body mass index (BMI) [62]. Obesity is associated with various alterations of the NK cell phenotype. Studies demonstrated that the expression level of the functional marker TRAIL and the activating NK receptor NKp46 are reduced in obese people [63-65]. In contrast, studies showed a highly activated NK cells in obese people with increased expression levels of $\mathrm{CD} 69$, and programmed cell death protein (PD)-1, as well as the inhibitory receptors of NKB1, CD158b, CD158i, NKG2A/CD94 complex, and Siglec-7 $[60,61,63,65]$. In addition, the expressions of CD16, and the adhesion molecule CD62L, and the maturation and differentiation marker CD27 on NK cells are downregulated in obese people [63]. Despite the enhanced activation, NK cells showed a decreased expression level of degranulating marker CD107a and decreased secretion of granzym B and perforin as well as the macrophage inflammatory protein (MIP)- $1 \beta$ in response to cancer cell lines in obese people $[61,64,65]$. Furthermore, the cytotoxicity of NK cells against cancer cells is significantly impaired in obese humans [61,63]. Aside from the characterization of total NK cells, the impact of obesity on the CD56 $6^{\text {dim }}$ and CD56 ${ }^{\text {bright }}$ subset-specific NK cell phenotype has recently been investigated, which demonstrated decreases in NKG2D-positive and CD69-positive CD56 ${ }^{\mathrm{dim}}$ NK cells, while there was an increase in NKG2D-positive CD56 $6^{\text {bright }} \mathrm{NK}$ cells in obese people. In addition, a study of cytokine production demonstrated a decreased expression level of IFN- $\gamma$ positive CD56 dim NK cells, while there was an increased expression of IFN- $\gamma$ positive CD56 ${ }^{\text {bright }} \mathrm{NK}$ cells in obese people. These alterations are correlated with BMI [62]. Therefore, obesity is associated with alterations of NK cell frequency and phenotypes and an impaired capacity to defend against cancer cells and virus-infected cells [61,63], which contribute to a higher cancer risk and susceptibility to viral infections in obese people. However, weight loss was found to reverse the obesity-induced defects in NK cells [62,96,97].

\subsection{Sleep Deprivation}

Sleep has a critical role in promoting health [98]. Sleep affects two primary effector systems, the HPA axis and the sympathetic nervous system (SNS), which in turn regulate immune responses [98,99]. NK cell activity is dependent in part on sleep. NK cell count and activity are minimum during the early part of the night and reach the maximum in the late morning hours [100]. There is a positive association between sleep time and efficiency with NK cell activity [101]. Loss of sleep at night resulted in decreases in both the number of NK cells and NK cell activity. After a night of recovery sleep, NK cell activity returned to baseline levels $[66,67]$. In addition, one night of sleep deprivation decreased NK activity [68]. In contrast, two nights of sleep deprivation increased NK activity [69]. The alterations of NK cell triggered by sleep loss were found to be mediated through augmented levels of glucocorticoids and catecholamine [99]. The resulting reduction in NK cell activity increased the vulnerability to cancer and viral infections.

\subsection{Exercise}

People who exercise almost daily have a reduced number of days of sickness [70,102]. Research has shown that positive immunological changes occur during moderate exercise [103]. NK cells have attracted the attention of exercise scientists for more than 30 years [104]. It has been reported that acute physical exercise strongly affects the NK cell count in peripheral blood [105]. The NK cell number increases immediately after cessation of exercise, followed by transient decreases in NK cell count and activity. Depending on the exercise regime (type, duration, and intensity), the decreases have been observed after $15-30 \mathrm{~min}$ and can persist for more than $24 \mathrm{~h}[105,106]$. NK cells are rapidly mobilized into the circulation in response to acute exercise, most likely by epinephrine-dependent $\beta$-adrenergic signaling $[107,108]$. This mobilization primarily affects CD56 dim NK cells and is driven by the expression of adhesion molecules of CD11a and CX3CR1 [107,109]. In view of the physical fitness level, studies unanimously revealed an increased NK cell activity in subjects with good physical constitution [70-74]. NK cell count and activity 
are increased in racing cyclists compared with nonathletes [71]. Consistent with these findings, athletes were found to have higher NK cell count and activity [72,74]. People with exercise habits have higher counts of NK cells and perforin-, granulysin-, granzyme A/B- expressing NK cells [49]. Therefore, exercise habits strengthen the NK cell function to defend against cancer and viral infections.

\subsection{Forest Bathing}

A forest bathing trip is a short, leisurely visit to a forest and is regarded as being similar to natural aromatherapy. Incorporating forest bathing trips into a good lifestyle was first proposed in 1982 by the Forest Agency of Japan. The results of studies using the Profile of Mood States test demonstrated that a forest bathing trip significantly increased the score for vigor and decreased the scores for anxiety, depression, and anger [75,76]. Forest bathing stabilizes autonomic nervous activity and significantly decreases the concentrations of stress hormones such as adrenaline and noradrenaline $[75,77,78]$. The frequency and count of NK cells, and the expression levels of granulysin, perforin, and granzymes A/B on NK cells increased on the forest bathing days, resulting in an increase in NK cell activity $[75-79,110]$. The increased NK cell activity lasted for more than 30 days after the trip $[75,77,79]$. The mechanisms underlying the increased NK cell activity during forest bathing may be partially related to an attenuated stress hormone response and also to breathing in of volatile organic compounds, called phytoncides produced by trees, such as $\alpha$-pinene and limonene [75-77,110]. In vitro research data indicate that phytoncides increase NK cell activity in a dose-dependent manner and prevent dichlovos-induced inhibition of NK cell activity [79]. Therefore, forest bathing trips have a positive effect on immunosurveillance against cancer and viral infections.

\subsection{Music}

Music therapy has attracted the attention of various fields such as psychiatry and geriatrics. Music therapy improves mood states by decreasing tension/anxiety, depression/dejection, anger/hostility, fatigue/inertia, and confusion/bewilderment and increases vigor/activity [80,81,111,112]. Music reduces the levels of stress hormones [113] and provides relief from stress [114,115]. The frequency of NK cells and NK cell activity are increased after music therapy [80,82]. Therefore, music provides a "wellness environment", which improves defense against cancer and viral infections.

\section{Aging with NK Cells}

Aging is accompanied by dysregulated immune function that contributes to an increased susceptibility to diseases, such as cancer and infections [116]. Physiological aging is associated with changes in the composition, phenotype, and function of circulating NK cells [117]. Studies to date have shown the effects of aging on human NK cells (Table 2). Significant increases in the percentage and absolute number of NK cells are the general observations reported [118-120]. Regarding to NK cell subsets, studies have shown that the proportions and number of CD56 ${ }^{\text {dim }}$ NK cells increases with age $[118,120,121]$, and older adults possess significantly fewer CD56 ${ }^{\text {bright }} \mathrm{NK}$ cells [118-121], resulting in a marked age-related increase in the CD56 ${ }^{\mathrm{dim}}: \mathrm{CD} 56^{\text {bright }}$ ratio $[118,120,121]$. Regarding the effects of aging on the NK cell phenotype, there is an age-related decrease in the expression level of activating receptors, such as NKp30 and/or NKp46 [118,120], and the expression levels of inhibitory receptors such as CD94 and/or NKG2A also show age-associated reductions $[118,120,121]$. Additionally, the proportion of CD57, a marker of NK maturity, is higher in older adults [120], whereas the expression level of CD69, an activation marker, increases with aging [119]. However, the increased expression level of CD57 on NK cells has been shown to be affected by infection by viruses, such as human cytomegalovirus [122]. CD57 is not necessarily a marker of aging/immunosenescence [123]. Importantly, aging is accompanied by decreased NK cell activity, which may be due to an age-associated impairment in perforin secretion [120]. Prospective studies have demonstrated that low 
NK cell activity is associated with an increased susceptibility to viral infections [124] and cancer [35].

Table 2. Overview of Aging Associated Alterations of Human NK Cells.

\begin{tabular}{|c|c|c|c|c|c|c|c|}
\hline Study & $\begin{array}{l}\text { NK Cells } \\
\text { Count }\end{array}$ & NK Cell (\%) & $\begin{array}{l}\text { NK Cell } \\
\text { Subsets }\end{array}$ & $\begin{array}{c}\text { Receptors } \\
\text { Expression on } \\
\text { NK Cell }\end{array}$ & NK Activity & $\begin{array}{l}\text { Chemokine } \\
\text { and Cytokine } \\
\text { Production }\end{array}$ & $\begin{array}{c}\text { Functional } \\
\text { Granule } \\
\text { Components }\end{array}$ \\
\hline $\begin{array}{c}\text { Almeida-Oliveira } \\
\text { A et al. [118] }\end{array}$ & $\uparrow$ & $\uparrow$ & $\begin{array}{c}\text { CD56 }^{\text {bright }} \downarrow \\
\text { CD56 } \\
\text { dim } \uparrow\end{array}$ & $\begin{array}{c}\text { NKp46 } \\
\text { NKp30 } \downarrow, \text { CD94 }\end{array}$ & $\mathrm{N} / \mathrm{A}$ & $\mathrm{N} / \mathrm{A}$ & $\mathrm{N} / \mathrm{A}$ \\
\hline $\begin{array}{l}\text { Le Garff-Tavernier } \\
\text { M, et al. [119] }\end{array}$ & $\uparrow$ & $\leftrightarrow$ & CD56 ${ }^{\text {bright }} \downarrow$ & CD69个 & $\leftrightarrow$ & IFN- $\gamma \leftrightarrow$ & $\mathrm{N} / \mathrm{A}$ \\
\hline $\begin{array}{l}\text { Hazeldine } \\
\text { J et al. [120] }\end{array}$ & $\mathrm{N} / \mathrm{A}$ & $\uparrow$ & $\begin{array}{c}\text { CD56 }{ }^{\text {bright }} \downarrow \text {, } \\
\text { CD56 } 6^{\text {dim } \uparrow}\end{array}$ & 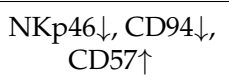 & $\downarrow$ & $\mathrm{N} / \mathrm{A}$ & Perforin $\downarrow$ \\
\hline Lutz CT et al. [121] & $\mathrm{N} / \mathrm{A}$ & $\mathrm{N} / \mathrm{A}$ & $\begin{array}{l}\text { CD56 }{ }^{\text {bright }} \downarrow \\
\text { CD56 } \\
\text { dim } \uparrow\end{array}$ & $\mathrm{NKG} 2 \mathrm{~A} \downarrow$ & $\mathrm{N} / \mathrm{A}$ & $\mathrm{N} / \mathrm{A}$ & $\mathrm{N} / \mathrm{A}$ \\
\hline
\end{tabular}

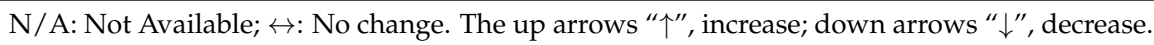

\section{Immunosurveillance of Cancer and Viral Infections by Healthy NK Cells}

NK cells are lymphocytes of the innate immune system, which can deal promptly with stressed cells, such as cancer cells and virus-infected cells, while also regulating the body's adaptive immunoresponses [125]. However, alterations in NK cells are associated with certain lifestyles [47,49,124,126] and aging [117]. Personal lifestyles, such as cigarette smoking, alcohol consumption, stress, obesity, and aging are associated with NK cell dysfunction, whereas adequate sleep, exercise, forest bathing, and listening to enjoyable music are associated with a healthy NK cell function (Figure 2). Therefore, adherence to a healthy lifestyle is essential and will be favorable to the immunosurveillance of cancer and viral infections with functional healthy NK cells.

\section{Healthy NK cell}

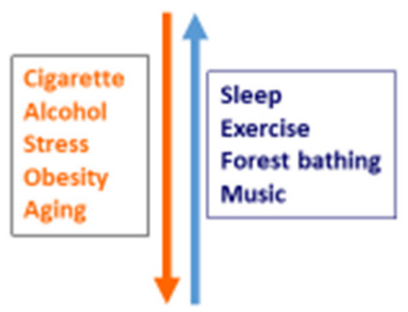

\section{Dysfunctional NK cell}

Figure 2. Schematic short list of the impacts of lifestyles and aging on NK cells. Cigarette smoking, alcohol consumption, stress, obesity, and aging suppress NK cell function, leading to a dysfunctional NK cells, whereas sleep, exercise, forest bathing, and listening to music enhance NK cell function with maintained functional healthy NK cells.

\section{Future Directions}

Although there are many confounding factors for the associations among lifestyle, NK cells, and cancer or viral infections, future research is needed to provide scientific evidence of immunosurveillance of cancer and viral infections in relation to the alterations of NK cells caused by lifestyles and aging. Clinical studies are also necessary to clarify the importance of improving lifestyles in disease prevention.

For disease treatment using NK cells, NK-cell-based adoptive immunotherapy has been introduced for cancer treatment and has been considered for viral infections $[19,127,128]$. To obtain convincing evidence of the importance of NK cells for disease treatment, it is 
necessary to treat cancer or viral infections using the combination of NK cell therapy and lifestyle improvement. To this end, further studies are necessary.

\section{Conclusions}

NK cells play key roles in the innate elimination of cancer cells and virus-infected cells. Alterations of NK cells are associated with lifestyles and aging. Adherence to a healthy lifestyle is essential and will be favorable to the immunosurveillance of cancer and viral infections with healthy NK cells.

Author Contributions: Conceptualization, X.D. and H.T.; writing-original draft preparation, X.D.; writing-review and editing, H.T. and M.N. All authors have read and agreed to the published version of the manuscript.

Funding: This research received no external funding.

Institutional Review Board Statement: Not applicable.

Informed Consent Statement: Not applicable.

Data Availability Statement: Data sharing not applicable.

Conflicts of Interest: X.D., H.T. and M.N. hold patents for feeder-cell-free NK cell expansion culture technology and are stock holders of Biotherapy Institution of Japan Inc., a biotech startup company developing NK-cell-based immunotherapy and Mesenchymal Stromal Cell (MSC)-based products, such as adipose MSCs, and MSC-derived conditioned medium (CM) concentrates and extracellular vesicle $(\mathrm{EV})$ isolates $\left(\right.$ StemSup $\left.{ }^{\circledR}\right)$ for clinical research.

\section{References}

1. GBD 2016 Disease and Injury Incidence and Prevalence Collaborators. Global, regional, and national age-sex specific mortality for 264 causes of death, 1980-2016: A systematic analysis for the Global Burden of Disease Study 2016. Lancet 2017, 390, 1151-1210. [CrossRef]

2. Kassebaum, N.J.; Arora, M.; Barber, R.M.; Bhutta, Z.A.; Brown, J.; Carter, A.; Casey, D.C.; Charlson, F.; Coates, M.M.; Coggeshall, M.; et al. Global, regional, and national disability-adjusted life-years (DALYs) for 315 diseases and injuries and healthy life expectancy (HALE), 1990-2015: A systematic analysis for the Global Burden of Disease Study 2015. Lancet 2016, 388, 1603-1658. [CrossRef]

3. Capocaccia, R.; Gatta, G.; Maso, L.D. Life expectancy of colon, breast, and testicular cancer patients: An analysis of US-SEER population-based data. Ann. Oncol. 2015, 26, 1263-1268. [CrossRef] [PubMed]

4. Loef, M.; Walach, H. The combined effects of healthy lifestyle behaviors on all cause mortality: A systematic review and meta-analysis. Prev. Med. 2012, 55, 163-170. [CrossRef]

5. Li, Y.; Schoufour, J.; Wang, D.D.; Dhana, K.; Pan, A.; Liu, X.; Song, M.; Liu, G.; Shin, H.J.; Sun, Q.; et al. Healthy lifestyle and life expectancy free of cancer, cardiovascular disease, and type 2 diabetes: Prospective cohort study. BMJ 2020, 368, 16669. [CrossRef]

6. Hamer, M.; Kivimäki, M.; Gale, C.R.; Batty, G.D. Lifestyle risk factors, inflammatory mechanisms, and COVID-19 hospitalization: A community-based cohort study of 387,109 adults in UK. Brain Behav. Immun. 2020, 87, 184-187. [CrossRef]

7. Peisch, S.F.; Van Blarigan, E.L.; Chan, J.M.; Stampfer, M.J.; Kenfield, S.A. Prostate cancer progression and mortality: A review of diet and lifestyle factors. World J. Urol. 2017, 35, 867-874. [CrossRef]

8. Kiessling, R.; Klein, E.; Wigzell, H. "Natural” killer cells in the mouse. I. Cytotoxic cells with specificity for mouse Moloney leukemia cells. Specificity and distribution according to genotype. Eur. J. Immunol. 1975, 5, 112-117. [CrossRef]

9. Herberman, R.B.; Nunn, M.E.; Holden, H.T.; Lavrin, D.H. Natural cytotoxic reactivity of mouse lymphoid cells against syngeneic and allogeneic tumors. II. Characterization of effector cells. Int. J. Cancer 1975, 16, 230-239. [CrossRef]

10. Frey, M.; Packianathan, N.B.; Fehniger, T.A.; Ross, M.E.; Wang, W.C.; Stewart, C.C.; Caligiuri, M.A.; Evans, S.S. Differential expression and function of L-selectin on CD56bright and CD56dim natural killer cell subsets. J. Immunol 1998, 161, 400-408. [PubMed]

11. Cooper, M.A.; Fehniger, T.A.; Caligiuri, M.A. The biology of human natural killer-cell subsets. Trends Immunol. 2001, 22, 633-640. [CrossRef]

12. Fehniger, T.A.; Cooper, M.A.; Nuovo, G.J.; Cella, M.; Facchetti, F.; Colonna, M.; Caligiuri, M.A. CD56bright natural killer cells are present in human lymph nodes and are activated by T cell-derived IL-2: A potential new link between adaptive and innate immunity. Blood 2003, 101, 3052-3057. [CrossRef] [PubMed]

13. Michel, T.; Poli, A.; Cuapio, A.; Briquemont, B.; Iserentant, G.; Ollert, M.; Zimmer, J. Human CD56bright NK Cells: An Update. J. Immunol. 2016, 196, 2923-2931. [CrossRef] [PubMed]

14. Leibson, P.J. Signal Transduction during Natural Killer Cell Activation: Inside the Mind of a Killer. Immunity 1997, 6, 655-661. [CrossRef] 
15. Lanier, L.L. Up on the tightrope: Natural killer cell activation and inhibition. Nat. Immunol. 2008, 9, 495-502. [CrossRef] [PubMed]

16. Long, E.O.; Kim, H.S.; Liu, D.; Peterson, M.E.; Rajagopalan, S. Controlling Natural Killer Cell Responses: Integration of Signals for Activation and Inhibition. Annu. Rev. Immunol. 2013, 31, 227-258. [CrossRef]

17. Kärre, K. NK Cells, MHC Class I Molecules and the Missing Self. Scand. J. Immunol. 2002, 55, 221-228. [CrossRef]

18. Vivier, E.; Tomasello, E.; Baratin, M.; Walzer, T.; Ugolini, S. Functions of natural killer cells. Nat. Immunol. 2008, 9, 503-510. [CrossRef]

19. Terunuma, H.; Deng, X.; Dewan, Z.; Fujimoto, S.; Yamamoto, N. Potential Role of NK Cells in the Induction of Immune Responses: Implications for NK Cell-Based Immunotherapy for Cancers and Viral Infections. Int. Rev. Immunol. 2008, 27, 93-110. [CrossRef]

20. Schuster, I.S.; Coudert, J.D.; Andoniou, C.E.; Degli-Esposti, M.A. "Natural Regulators": NK Cells as Modulators of T Cell Immunity. Front. Immunol. 2016, 7, 235. [CrossRef]

21. Jost, S.; Altfeld, M. Control of Human Viral Infections by Natural Killer Cells. Annu. Rev. Immunol. 2013, 31, 163-194. [CrossRef]

22. Brandstadter, J.D.; Yang, Y. Natural Killer Cell Responses to Viral Infection. J. Innate Immun. 2011, 3, 274-279. [CrossRef] [PubMed]

23. Orange, J.S. Human natural killer cell deficiencies and susceptibility to infection. Microbes Infect. 2002, 4, 1545-1558. [CrossRef]

24. Biron, C.A.; Byron, K.S.; Sullivan, J.L. Severe Herpesvirus Infections in an Adolescent without Natural Killer Cells. N. Engl. J. Med. 1989, 320, 1731-1735. [CrossRef] [PubMed]

25. Van Eeden, C.; Khan, L.; Osman, M.S.; Tervaert, J.W.C. Natural Killer Cell Dysfunction and its Role in COVID-19. Int. J. Mol. Sci. 2020, 21, 6351. [CrossRef]

26. Bukowski, J.F.; Woda, B.A.; Habu, S.; Okumura, K.; Welsh, R.M. Natural killer cell depletion enhances virus synthesis and vi-rus-induced hepatitis in vivo. J. Immunol 1983, 131, 1531-1538. [PubMed]

27. Lee, S.-H.; Miyagi, T.; Biron, C.A. Keeping NK cells in highly regulated antiviral warfare. Trends Immunol. 2007, 28, 252-259. [CrossRef]

28. Ljunggren, H.G.; Kärre, K. Host resistance directed selectively against H-2-deficient lymphoma variants. Analysis of the mechanism. J. Exp. Med. 1985, 162, 1745-1759. [CrossRef]

29. Kärre, K.; Ljunggren, H.G.; Piontek, G.; Kiessling, R. Selective rejection of H-2-deficient lymphoma variants suggests al-ternative immune defence strategy. Nature 1986, 319, 675-678. [CrossRef]

30. Wu, J.; Lanier, L.L. Natural Killer Cells and Cancer. Adv. Cancer Res. 2003, 90, 127-156. [CrossRef]

31. Guillerey, C.; Smyth, M.J. NK cells and cancer immunoediting. In Natural Killer Cells; Springer: Cham, Switzerland, 2015; pp. 115-145. [CrossRef]

32. Smyth, M.J.; Thia, K.Y.T.; Street, S.E.; Cretney, E.; Trapani, J.A.; Taniguchi, M.; Kawano, T.; Pelikan, S.B.; Crowe, N.Y.; Godfrey, D.I. Differential Tumor Surveillance by Natural Killer (Nk) and Nkt Cells. J. Exp. Med. 2000, 191, 661-668. [CrossRef] [PubMed]

33. Marcus, A.; Gowen, B.G.; Thompson, T.W.; Iannello, A.; Ardolino, M.; Deng, W.; Wang, L.; Shifrin, N.; Raulet, D.H. Recognition of tumors by the innate immune system and natural killer cells. Adv. Immunol. 2014, 122, 91-128. [PubMed]

34. Malmberg, K.-J.; Carlsten, M.; Björklund, A.; Sohlberg, E.; Bryceson, Y.T.; Ljunggren, H.-G. Natural killer cell-mediated immunosurveillance of human cancer. Semin. Immunol. 2017, 31, 20-29. [CrossRef] [PubMed]

35. Imai, K.; Matsuyama, S.; Miyake, S.; Suga, K.; Nakachi, K. Natural cytotoxic activity of peripheral-blood lymphocytes and cancer incidence: An 11-year follow-up study of a general population. Lancet 2000, 356, 1795-1799. [CrossRef]

36. Espí, A.; Arenas, J.; García-Granero, E.; Martí, E.; Lledó, S. Relationship of curative surgery on natural killer cell activity in colorectal cancer. Dis. Colon Rectum 1996, 39, 429-434. [CrossRef]

37. Barkin, J.; Rodriguez-Suarez, R.; Betito, K. Association between natural killer cell activity and prostate cancer: A pilot study. Can. J. Urol. 2017, 24, 8708-8713.

38. Dewan, Z.; Takada, M.; Terunuma, H.; Deng, X.; Ahmed, S.; Yamamoto, N.; Toi, M. Natural killer activity of peripheral-blood mononuclear cells in breast cancer patients. Biomed. Pharmacother. 2009, 63, 703-706. [CrossRef]

39. Coca, S.; Perez-Piqueras, J.; Martinez, D.; Colmenarejo, A.; Saez, M.A.; Vallejo, C.; Martos, J.A.; Moreno, M. The prognostic sig-nificance of intratumoral natural killer cells in patients with colorectal carcinoma. Cancer 1997, 79, 2320-2328. [CrossRef]

40. Donskov, F.; Von Der Maase, H. Impact of Immune Parameters on Long-Term Survival in Metastatic Renal Cell Carcinoma. J. Clin. Oncol. 2006, 24, 1997-2005. [CrossRef]

41. Rusakiewicz, S.; Semeraro, M.; Sarabi, M.; Desbois, M.; Locher, C.; Mendez, R.; Vimond, N.; Concha, A.; Garrido, F.; Isambert, N.; et al. Immune Infiltrates Are Prognostic Factors in Localized Gastrointestinal Stromal Tumors. Cancer Res. 2013, 73, 3499-3510. [CrossRef]

42. Hansen, T.F.; Nederby, L.; Zedan, A.H.; Mejlholm, I.; Henriksen, J.R.; Steffensen, K.D.; Thomsen, C.B.; Raunkilde, L.; Jensen, L.H.; Jakobsen, A. Correlation Between Natural Killer Cell Activity and Treatment Effect in Patients with Disseminated Cancer. Transl. Oncol. 2019, 12, 968-972. [CrossRef] [PubMed]

43. Mazzaschi, G.; Facchinetti, F.; Missale, G.; Canetti, D.; Madeddu, D.; Zecca, A.; Veneziani, M.; Gelsomino, F.; Goldoni, M.; Buti, S.; et al. The circulating pool of functionally competent NK and CD8+ cells predicts the outcome of anti-PD1 treatment in advanced NSCLC. Lung Cancer 2019, 127, 153-163. [CrossRef] [PubMed]

44. Choi, M.G.; Kim, Y.J.; Lee, J.C.; Rho, J.K.; Choi, C. Efficacy of natural killer cell activity as a biomarker for predicting immunotherapy response in non-small cell lung cancer. Thorac. Cancer 2020, 11, 3337-3345. [CrossRef] 
45. Takeuchi, M.; Nagai, S.; Izumi, T. Effect of Smoking on Natural Killer Cell Activity in the Lung. Chest 1988, 94, 688-693. [CrossRef] [PubMed]

46. Kusaka, Y.; Kondou, H.; Morimoto, K. Healthy lifestyles are associated with higher natural killer cell activity. Prev. Med. 1992, 21, 602-615. [CrossRef]

47. Morimoto, K.; Takeshita, T.; Inoue-Sakurai, C.; Maruyama, S. Lifestyles and mental health status are associated with natural killer cell and lymphokine-activated killer cell activities. Sci. Total. Environ. 2001, 270, 3-11. [CrossRef]

48. Jung, Y.S.; Park, J.H.; Park, D.I.; Sohn, C.I.; Lee, J.M.; Kim, T.I. Impact of Smoking on Human Natural Killer Cell Activity: A Large Cohort Study. J. Cancer Prev. 2020, 25, 13-20. [CrossRef]

49. Li, Q.; Morimoto, K.; Nakadai, A.; Qu, T.; Matsushima, H.; Katsumata, M.; Shimizu, T.; Inagaki, H.; Hirata, Y.; Hirata, K.; et al. Healthy lifestyles are associated with higher levels of perforin, granulysin and granzymes A/B-expressing cells in peripheral blood lymphocytes. Prev. Med. 2007, 44, 117-123. [CrossRef]

50. Ochshorn-Adelson, M.; Bodner, G.; Toraker, P.; Albeck, H.; Ho, A.; Kreek, M.J. Effects of Ethanol on Human Natural Killer Cell Activity: In Vitro and Acute, Low-Dose In Vivo Studies. Alcohol. Clin. Exp. Res. 1994, 18, 1361-1367. [CrossRef]

51. Laso, F.J.; Madruga, J.I.; Giron, J.A.; López, A.; Ciudad, J.; Miguel, J.F.S.; Alvarez-Mon, M.; Orfao, A. Decreased natural killer cytotoxic activity in chronic alcoholism is associated with alcohol liver disease but not active ethanol consumption. Hepatol. 1997, 25, 1096-1100. [CrossRef]

52. Perney, P.; Portalès, P.; Corbeau, P.; Roques, V.; Blanc, F.; Clot, J. Specific Alteration of Peripheral Cytotoxic Cell Perforin Expression in Alcoholic Patients: A Possible Role in Alcohol-Related Diseases. Alcohol. Clin. Exp. Res. 2003, 27, 1825-1830. [CrossRef] [PubMed]

53. Redwine, L.; Dang, J.; Hall, M.; Irwin, M. Disordered Sleep, Nocturnal Cytokines, and Immunity in Alcoholics. Psychosom. Med. 2003, 65, 75-85. [CrossRef]

54. Irwin, M.; Miller, C. Decreased natural killer cell responses and altered interleukin-6 and interleukin-10 production in alcoholism: An interaction between alcohol dependence and African-American ethnicity. Alcohol Clin. Exp. Res. 2000, 24, 560-569. [CrossRef]

55. Koga, C.; Itoh, K.; Aoki, M.; Suefuji, Y.; Yoshida, M.; Asosina, S.; Esaki, K.; Kameyama, T. Anxiety and pain suppress the natural killer cell activity in oral surgery outpatients. Oral Surg. Oral Med. Oral Pathol. Oral Radiol. Endodontol. 2001, 91, 654-658. [CrossRef] [PubMed]

56. Andersen, B.L.; Farrar, W.B.; Golden-Kreutz, D.; Kutz, L.A.; Maccallum, R.; Courtney, M.E.; Glaser, R. Stress and Immune Responses After Surgical Treatment for Regional Breast Cancer. J. Natl. Cancer Inst. 1998, 90, 30-36. [CrossRef]

57. Morikawa, Y.; Kitaoka-Higashiguchi, K.; Tanimoto, C.; Hayashi, M.; Oketani, R.; Miura, K.; Nishijo, M.; Nakagawa, H. A Cross-Sectional Study on the Relationship of Job Stress with Natural Killer Cell Activity and Natural Killer Cell Subsets among Healthy Nurses. J. Occup. Health 2005, 47, 378-383. [CrossRef]

58. Boscolo, P.; Di Donato, A.; Di Giampaolo, L.; Forcella, L.; Reale, M.; Dadorante, V.; Alparone, F.; Pagliaro, S.; Kouri, M.; Magrini, A.; et al. Blood natural killer activity is reduced in men with occupational stress and job insecurity working in a university. Int. Arch. Occup. Environ. Health 2008, 82, 787-794. [CrossRef]

59. Glaser, R.; Rice, J.; Speicher, C.E.; Stout, J.C.; Kiecolt-Glaser, J.K. Stress depresses interferon production by leukocytes concomitant with a decrease in natural killer cell activity. Behav. Neurosci. 1986, 100, 675-678. [CrossRef]

60. Lynch, L.A.; O'Connell, J.M.; Kwasnik, A.K.; Cawood, T.J.; O’Farrelly, C.; O'Shea, D.B. Are Natural Killer Cells Protecting the Metabolically Healthy Obese Patient? Obesity 2009, 17, 601-605. [CrossRef]

61. Tobin, L.M.; Mavinkurve, M.; Carolan, E.; Kinlen, D.; O’Brien, E.C.; Little, M.A.; Finlay, D.K.; Cody, D.; Hogan, A.E.; O’Shea, D. NK cells in childhood obesity are activated, metabolically stressed, and functionally deficient. JCI Insight 2017, 2, 94939. [CrossRef]

62. Bähr, I.; Jahn, J.; Zipprich, A.; Pahlow, I.; Spielmann, J.; Kielstein, H. Impaired natural killer cell subset phenotypes in human obesity. Immunol. Res. 2018, 66, 234-244. [CrossRef]

63. Naujoks, W.; Quandt, D.; Hauffe, A.; Kielstein, H.; Bähr, I.; Spielmann, J. Characterization of Surface Receptor Expression and Cytotoxicity of Human NK Cells and NK Cell Subsets in Overweight and Obese Humans. Front. Immunol. 2020, 11, 573200. [CrossRef]

64. TobiasLaue, T.; Wrann, C.D.; Hoffmann-Castendiek, B.; Pietsch, D.; Hübner, L.; Kielstein, H. Altered NK cell function in obese healthy humans. BMC Obes. 2015, 2, 1-10. [CrossRef]

65. Viel, S.; Besson, L.; Charrier, E.; Marçais, A.; Disse, E.; Bienvenu, J.; Walzer, T.; Dumontet, C. Alteration of Natural Killer cell phenotype and function in obese individuals. Clin. Immunol. 2017, 177, 12-17. [CrossRef]

66. Irwin, M.; Mascovich, A.; Gillin, J.C.; Willoughby, R.; Pike, J.; Smith, T.L. Partial sleep deprivation reduces natural killer cell activity in humans. Psychosom. Med. 1994, 56, 493-498. [CrossRef]

67. Irwin, M.; McClintick, J.; Costlow, C.; Fortner, M.; White, J.; Gillin, J.C. Partial night sleep deprivation reduces natural killer and celhdar immune responses in humans. FASEB J. 1996, 10, 643-653. [CrossRef]

68. Moldofsky, H.; Lue, F.A.; Davidson, J.R.; Gorczynski, R. Effects of sleep deprivation on human immune functions. FASEB J. 1989, 3, 1972-1977. [CrossRef] [PubMed]

69. Dinges, D.F.; Douglas, S.D.; Zaugg, L.; Campbell, D.E.; McMann, J.M.; Whitehouse, W.G.; Orne, E.C.; Kapoor, S.C.; Icaza, E.; Orne, M.T. Leukocytosis and natural killer cell function parallel neurobehavioral fatigue induced by 64 hours of sleep deprivation. $J$. Clin. Investig. 1994, 93, 1930-1939. [CrossRef] 
70. Nieman, D.C.; Henson, D.A.; Gusewitch, G.; Warren, B.J.; Dotson, R.C.; Butterworth, D.E.; Nehlsen-Cannarella, S.L. Physical activity and immune function in elderly women. Med. Sci. Sports Exerc. 1993, 25, 823-831. [CrossRef]

71. Pedersen, B.; Tvede, N.; Christensen, L.; Klarlund, K.; Kragbak, S.; Halkjr-Kristensen, J. Natural Killer Cell Activity in Peripheral Blood of Highly Trained and Untrained Persons. Int. J. Sports Med. 1989, 10, 129-131. [CrossRef] [PubMed]

72. Moro-García, M.A.; Fernández-García, B.; Echeverría, A.; Rodríguez-Alonso, M.; Suárez-García, F.M.; Solano-Jaurrieta, J.J.; López-Larrea, C.; Alonso-Arias, R. Frequent participation in high volume exercise throughout life is associated with a more differentiated adaptive immune response. Brain, Behav. Immun. 2014, 39, 61-74. [CrossRef]

73. Jung, Y.S.; Park, J.H.; Park, D.I.; Sohn, C.I.; Lee, J.M.; Kim, T.I. Physical Inactivity and Unhealthy Metabolic Status Are Associated with Decreased Natural Killer Cell Activity. Yonsei Med. J. 2018, 59, 554-562. [CrossRef]

74. Nieman, D.C.; Buckley, K.S.; Henson, D.A.; Warren, B.J.; Suttles, J.; Ahle, J.C.; Simandle, S.; Fagoaga, O.R.; Nehlsen-Cannarella, S.L. Immune function in marathon runners versus sedentary controls. Med. Sci. Sports Exerc. 1995, 27, 986-992. [CrossRef] [PubMed]

75. Li, Q.; Morimoto, K.; Kobayashi, M.; Inagaki, H.; Katsumata, M.; Hirata, Y.; Hirata, K.; Shimizu, T.; Li, Y.J.; Wakayama, Y.; et al. A forest bathing trip increases human natural killer activity and ex-pression of anti-cancer proteins in female subjects. J. Biol. Regul. Homeost Agents 2008, 22, 45-55.

76. Li, Q.; Morimoto, K.; Nakadai, A.; Inagaki, H.; Katsumata, M.; Shimizu, T.; Hirata, Y.; Hirata, K.; Suzuki, H.; Miyazaki, Y.; et al. Forest Bathing Enhances Human Natural Killer Activity and Expression of Anti-Cancer Proteins. Int. J. Immunopathol. Pharmacol. 2007, 20, 3-8. [CrossRef]

77. Li, Q.; Morimoto, K.; Kobayashi, M.; Inagaki, H.; Katsumata, M.; Hirata, Y.; Hirata, K.; Suzuki, H.; Li, Y.; Wakayama, Y.; et al. Visiting a Forest, but Not a City, Increases Human Natural Killer Activity and Expression of Anti-Cancer Proteins. Int. J. Immunopathol. Pharmacol. 2008, 21, 117-127. [CrossRef]

78. Li, Q.; Kobayashi, M.; Inagaki, H.; Hirata, Y.; Li, Y.J.; Hirata, K.; Shimizu, T.; Suzuki, H.; Katsumata, M.; Wakayama, Y.; et al. A day trip to a forest park increases human natural killer activity and the expression of anti-cancer proteins in male subjects. J. Boil. Regul. Homeost. agents 2010, 24, 157-165.

79. Li, Q. Effect of forest bathing trips on human immune function. Environ. Health Prev. Med. 2009, 15, 9-17. [CrossRef]

80. Wachi, M.; Koyama, M.; Utsuyama, M.; Bittman, B.B.; Kitagawa, M.; Hirokawa, K. Recreational music-making modulates natural killer cell activity, cytokines, and mood states in corporate employees. Med. Sci. Monit. 2007, 13, CR57-70.

81. Koyama, M.; Wachi, M.; Utsuyama, M.; Bittman, B.; Hirokawa, K.; Kitagawa, M. Recreational music-making modulates im-munological responses and mood states in older adults. J. Med. Dent. Sci 2009, 56, 79-90.

82. Hasegawa, Y.; Kubota, N.; Inagaki, T.; Shinagawa, N. Music Therapy Induced Alternations in Natural Killer Cell Count and Function. Nippon. Ronen Igakkai Zasshi. Jpn. J. Geriatr. 2001, 38, 201-204. [CrossRef] [PubMed]

83. Ordóñez-Mena, J.M.; Schoettker, B.; Mons, U.; Jenab, M.; Freisling, H.; Bueno-De-Mesquita, B.; O’Doherty, M.G.; Scott, A.; Kee, F.; Stricker, B.H.; et al. Quantification of the smoking-associated cancer risk with rate advancement periods: Meta-analysis of individual participant data from cohorts of the CHANCES consortium. BMC Med. 2016, 14, 1-15. [CrossRef]

84. Lu, L.-M.; Zavitz, C.C.J.; Chen, B.; Kianpour, S.; Wan, Y.; Stämpfli, M.R. Cigarette Smoke Impairs NK Cell-Dependent Tumor Immune Surveillance. J. Immunol. 2007, 178, 936-943. [CrossRef] [PubMed]

85. Mufti, S.I.; Darban, H.R.; Watson, R.R. Alcohol, cancer, and immunomodulation. Crit. Rev. Oncol. 1989, 9, 243-261. [CrossRef]

86. Kaplan, D.R. A novel mechanism of immunosuppression mediated by ethanol. Cell. Immunol. 1986, 102, 1-9. [CrossRef]

87. MacGregor, R.R. Alcohol and immune defense. JAMA 1986, 256, 1474-1479. [CrossRef] [PubMed]

88. Schedlowski, M.; Schmidt, R.E. Stress and the immune system. Naturwissenschaften 1996, 83, 214-220. [CrossRef]

89. Pike, J.L.; Smith, T.L.; Hauger, R.L.; Nicassio, P.M.; Patterson, T.L.; McClintick, J.; Costlow, C.; Irwin, M.R. Chronic Life Stress Alters Sympathetic, Neuroendocrine, and Immune Responsivity to an Acute Psychological Stressor in Humans. Psychosom. Med. 1997, 59, 447-457. [CrossRef]

90. Ben-Eliyahu, S.; Shakhar, G.; Page, G.G.; Stefanski, V.; Shakhar, K. Suppression of NK Cell Activity and of Resistance to Metastasis by Stress: A Role for Adrenal Catecholamines and $\beta$-Adrenoceptors. Neuroimmunomodulation 2000, 8, 154-164. [CrossRef]

91. Guh, D.P.; Zhang, W.; Bansback, N.; Amarsi, Z.; Birmingham, C.L.; Anis, A.H. The incidence of co-morbidities related to obesity and overweight: A systematic review and meta-analysis. BMC Public Health 2009, 9, 88. [CrossRef]

92. Hussain, A.; Mahawar, K.; Xia, Z.; Yang, W.; El-Hasani, S. RETRACTED: Obesity and mortality of COVID-19. Meta-analysis. Obes. Res. Clin. Pr. 2020, 14, 295-300. [CrossRef] [PubMed]

93. Steele, C.B.; Thomas, C.C.; Henley, S.J.; Massetti, G.M.; Galuska, D.A.; Agurs-Collins, T.; Puckett, M.; Richardson, L.C. Vital Signs: Trends in Incidence of Cancers Associated with Overweight and Obesity-United States, 2005-2014. MMWR. Morb. Mortal. Wkly. Rep. 2017, 66, 1052-1058. [CrossRef] [PubMed]

94. Weisberg, S.P.; McCann, D.; Desai, M.; Rosenbaum, M.; Leibel, R.L.; Ferrante, A.W., Jr. Obesity is associated with macrophage accumulation in adipose tissue. J. Clin. Investig. 2003, 112, 1796-1808. [CrossRef]

95. Michelet, X.; Dyck, L.; Hogan, A.; Loftus, R.M.; Duquette, D.; Wei, K.; Beyaz, S.; Tavakkoli, A.; Foley, C.; Donnelly, R.; et al. Metabolic reprogramming of natural killer cells in obesity limits antitumor responses. Nat. Immunol. 2018, 19, 1330-1340. [CrossRef] 
96. Moulin, C.M.; Marguti, I.; Peron, J.P.S.; Halpern, A.; Rizzo, L.V. Bariatric Surgery Reverses Natural Killer (NK) Cell Activity and NK-Related Cytokine Synthesis Impairment Induced by Morbid Obesity. Obes. Surg. 2011, 21, 112-118. [CrossRef]

97. Jahn, J.; Spielau, M.; Brandsch, C.; Stangl, G.I.; Delank, K.-S.; Bähr, I.; Berreis, T.; Wrann, C.D.; Kielstein, H. Decreased NK cell functions in obesity can be reactivated by fat mass reduction. Obesity 2015, 23, 2233-2241. [CrossRef]

98. Irwin, M.R. Why Sleep Is Important for Health: A Psychoneuroimmunology Perspective. Annu. Rev. Psychol. 2015, 66, 143-172. [CrossRef]

99. De Lorenzo, B.H.; Marchioro, L.D.O.; Greco, C.R.; Suchecki, D. Sleep-deprivation reduces NK cell number and function mediated by $\beta$-adrenergic signalling. Psychoneuroendocrinology 2015, 57, 134-143. [CrossRef]

100. Kronfol, Z.; Nair, M.; Zhang, Q.; Hill, E.E.; Brown, M.B. Circadian Immune Measures in Healthy Volunteers. Psychosom. Med. 1997, 59, 42-50. [CrossRef]

101. Irwin, M.; Smith, T.L.; Gillin, J.C. Electroencephalographic sleep and natural killer activity in depressed patients and control subjects. Psychosom. Med. 1992, 54, 10-21. [CrossRef]

102. Nieman, D.C.; Nehlsen-Cannarella, S.L.; Markoff, P.A.; Balk-Lamberton, A.J.; Yang, H.; Chritton, D.B.W.; Lee, J.W.; Arabatzis, K. The Effects of Moderate Exercise Training on Natural Killer Cells and Acute Upper Respiratory Tract Infections. Int. J. Sports Med. 1990, 11, 467-473. [CrossRef] [PubMed]

103. Nieman, D.C. Current Perspective on Exercise Immunology. Curr. Sports Med. Rep. 2003, 2, 239-242. [CrossRef] [PubMed]

104. Zimmer, P.; Schenk, A.; Kieven, M.; Holthaus, M.; Lehmann, J.; Lövenich, L.; Bloch, W. Exercise induced alterations in NK-cell cytotoxicity-Methodological issues and future perspectives. Exerc. Immunol. Rev. 2017, 23, 66-81. [PubMed]

105. Pedersen, B.K.; Tvede, N. The immune system and physical training. Ugeskr. Laeger 1993, 155, 856-862. [PubMed]

106. Walsh, N.P.; Gleeson, M.; Shephard, R.J.; Gleeson, M.; Woods, J.A.; Bishop, N.C.; Fleshner, M.; Green, C.; Pedersen, B.K.; Hoff-man-Goetz, L.; et al. Position statement. Part one: Immune function and exercise. Exerc. Immunol. Rev. 2011, 17, 6-63.

107. Dimitrov, S.; Lange, T.; Born, J. Selective Mobilization of Cytotoxic Leukocytes by Epinephrine. J. Immunol. 2009, 184, 503-511. [CrossRef]

108. Nagatomi, R.; Kaifu, T.; Okutsu, M.; Zhang, X.; Kanemi, O.; Ohmori, H. Modulation of the immune system by the auto-nomic nervous system and its implication in immunological changes after training. Exerc. Immunol. Rev. 2000, 6, 54-74.

109. Timmons, B.W.; Cieslak, T. Human natural killer cell subsets and acute exercise: A brief review. Exerc. Immunol. Rev. 2008, 14, 8-23. [PubMed]

110. Li, Q.; Nakadai, A.; Matsushima, H.; Miyazaki, Y.; Krensky, A.M.; Kawada, T.; Morimoto, K. Phytoncides (Wood Essential Oils) Induce Human Natural Killer Cell Activity. Immunopharmacol. Immunotoxicol. 2006, 28, 319-333. [CrossRef]

111. Bittman, B.; Bruhn, K.T.; Stevens, C.; Westengard, J.; Umbach, P.O. Recreational music-making: A cost-effective group interdisciplinary strategy for reducing burnout and improving mood states in long-term care workers. Adv. Mind Body Med. 2003, 19, 4-15.

112. Bittman, B.B.; Snyder, C.; Bruhn, K.T.; Liebfreid, F.; Stevens, C.K.; Westengard, J.; O Umbach, P. Recreational Music-making: An Integrative Group Intervention for Reducing Burnout and Improving Mood States in First Year Associate Degree Nursing Students: Insights and Economic Impact. Int. J. Nurs. Educ. Sch. 2004, 1, Article12. [CrossRef] [PubMed]

113. Rider, M.S.; Floyd, J.W.; Kirkpatrick, J. The Effect of Music, Imagery, and Relaxation on Adrenal Corticosteroids and the Re-entrainment of Circadian Rhythms. J. Music. Ther. 1985, 22, 46-58. [CrossRef]

114. Knight, W.E.J.; Rickard, N.S. Relaxing Music Prevents Stress-Induced Increases in Subjective Anxiety, Systolic Blood Pressure, and Heart Rate in Healthy Males and Females. J. Music. Ther. 2001, 38, 254-272. [CrossRef] [PubMed]

115. Hayes, A.; Buffum, M.; Lanier, E.; Rodahl, E.; Sasso, C. A Music Intervention to Reduce Anxiety Prior to Gastrointestinal Procedures. Gastroenterol. Nurs. 2003, 26, 145-149. [CrossRef] [PubMed]

116. Pawelec, G.; Solana, R. Immunosenescence. Immunol. Today 1997, 18, 514-516. [CrossRef]

117. Hazeldine, J.; Lord, J.M. The impact of ageing on natural killer cell function and potential consequences for health in older adults. Ageing Res. Rev. 2013, 12, 1069-1078. [CrossRef]

118. Almeida-Oliveira, A.; Smith-Carvalho, M.; Porto, L.C.; Cardoso-Oliveira, J.; Ribeiro, A.D.S.; Falcão, R.R.; Abdelhay, E.; Bouzas, L.F.; Thuler, L.C.S.; Ornellas, M.H.; et al. Age-related changes in natural killer cell receptors from childhood through old age. Hum. Immunol. 2011, 72, 319-329. [CrossRef]

119. Le Garff-Tavernier, M.; Béziat, V.; Decocq, J.; Siguret, V.; Gandjbakhch, F.; Pautas, E.; Debré, P.; Merle-Beral, H.; Vieillard, V. Human NK cells display major phenotypic and functional changes over the life span. Aging Cell 2010, 9, 527-535. [CrossRef]

120. Hazeldine, J.; Hampson, P.; Lord, J.M. Reduced release and binding of perforin at the immunological synapse underlies the age-related decline in natural killer cell cytotoxicity. Aging Cell 2012, 11, 751-759. [CrossRef]

121. Lutz, C.T.; Karapetyan, A.; Al-Attar, A.; Shelton, B.J.; Holt, K.J.; Tucker, J.H.; Presnell, S.R. Human NK Cells Proliferate and Die In Vivo More Rapidly than T Cells in Healthy Young and Elderly Adults. J. Immunol. 2011, 186, 4590-4598. [CrossRef]

122. Lopez-Vergès, S.; Milush, J.M.; Schwartz, B.S.; Pando, M.J.; Jarjoura, J.; York, V.A.; Houchins, J.P.; Miller, S.; Kang, S.-M.; Norris, P.J.; et al. Expansion of a unique CD57+NKG2Chi natural killer cell subset during acute human cytomegalovirus infection. Proc. Natl. Acad. Sci. USA 2011, 108, 14725-14732. [CrossRef] [PubMed] 
123. Chong, L.K.; Aicheler, R.J.; Llewellyn-Lacey, S.; Tomasec, P.; Brennan, P.; Wang, E.C.Y. Proliferation and interleukin 5 production by CD8hiCD57+ T cells. Eur. J. Immunol. 2008, 38, 995-1000. [CrossRef] [PubMed]

124. Ogata, K.; An, E.; Shioi, Y.; Nakamura, K.; Luo, S.; Yokose, N.; Minami, S.; Dan, K. Association between natural killer cell activity and infection in immunologically normal elderly people. Clin. Exp. Immunol. 2001, 124, 392-397. [CrossRef]

125. Lodoen, M.B.; Lanier, L.L. Natural killer cells as an initial defense against pathogens. Curr. Opin. Immunol. 2006, 18, $391-398$. [CrossRef] [PubMed]

126. O'Shea, D.; Hogan, A.E. Dysregulation of Natural Killer Cells in Obesity. Cancers 2019, 11, 573. [CrossRef] [PubMed]

127. Terunuma, H.; Deng, X.; Nishino, N.; Watanabe, K. NK cell-based autologous immune enhancement therapy (AIET) for cancer. J. stem cells Regen. Med. 2013, 9, 9-13. [CrossRef]

128. Bao, C.; Tao, X.; Cui, W.; Hao, Y.; Zheng, S.; Yi, B.; Pan, T.; Young, K.H.; Qian, W. Natural killer cells associated with SARS-CoV-2 viral RNA shedding, antibody response and mortality in COVID-19 patients. Exp. Hematol. Oncol. 2021, 10, 1-4. [CrossRef] 